\title{
Tensions, struggles and forbidden sexual relations in Noah's Ark: The narrative of the "uncalm ark" in the Aggadic homilies
}

\author{
Abraham Ofir Shemesh*
}

\begin{abstract}
The biblical text does not mention any events that occurred in the ark during the flood. The impression formed by the verses is that life in the ark involved no problems and everything seems to have proceeded smoothly $(7: 15-8: 19)$. The creatures in the ark, apparently, existed harmoniously side by side with no territorial boundaries, tensions, or rivalries. The current study discusses three midrashim that refute the impression formed by the text. The midrash portrays negative occurrences within the ark. One deals with forbidden sexual relations in the ark, the second relates to the rivalry and confrontation between the cat and the mouse, and the third is about the lion that injures Noah and renders him disabled. The midrashim relating that which occurred within the ark strengthen the insight whereby the evil urges of the creatures, and first and foremost of humankind, did not change, and the attempt to create a new ideal and sinless system did not meet with success.
\end{abstract}

Key words: Noah's Ark, The flood, Raven, cat and mouse, Midrash

The story of the Creation that opens the book of Genesis describes the formation of an allegedly ideal and perfect universal system. The phrase "And God saw that it was good" is repeated several times when describing the creation of the world (Genesis 1: 4, 10, 12, 18, 21, 25), and at the end of the process, the Creator reaches the conclusion that everything that was produced is "very good" (Genesis 1:31). Immediately afterwards, the idyll of an ideal world is shattered by a series of sins committed by Adam and his descendants. Adam and Eve eat of the prohibited Tree of Knowledge (3:6), Cain kills his brother Abel (4:8), and the entire human race declines and behaves corruptly $(6: 1-6,12)$ (on the process of the decline of the world see SKINNER, 1910, p. 149; KIL, 1997, p. 234-235).

\footnotetext{
* Israel Heritage Department. Faculty of Social Sciences and Humanities Ariel University. P.O.B. 3, Ariel 40700. Israel. avi0603@013.net.il .
} 
In Chapter 6 (1-8) the biblical narrator portrays the marriage of the sons of God with the daughters of man in Noah's generation as a negative occurrence that leads God to an insight concerning "man's evilness" and to a decision to eliminate all creatures, from humans to beasts, insects, and birds of the heavens (LOEWENSTAMM, 1968, V, p. 614-636; DALE, 1985, p. 77-78). The reason for the annihilation of the creatures is mentioned once again in the next verses (Genesis 6: 11-13). The scriptures note, fairly generally, that all the creatures corrupted their ways and sinned profusely (Genesis 6: 11: "Now the earth was corrupt in God's sight, and the earth was filled with violence"), ${ }^{1}$ but the nature of the sins is not clearly stated in the text. ${ }^{2}$ Following the verses, the Aggadic homilies ${ }^{3}$ attributed two major sins to Noah's generation - sexual corruption (prostitution, adultery, and zoophilia) and social-moral corruption, i.e., stealing (BABYLONIAN TALMUD, 1882, Sanhedrin 108b; HOROWITZ, 1917, p. 86; HOROWITZ, 1972, 51a; GENESIS RABBAH, 1885-1887, p. 113-114).

Following the corruption by the creatures, God decided to bring upon them a flood that will destroy all life on earth but left a small procreative nucleus from which the world would renew itself. In order to carry out His plan He commanded Noah to build an ark and gather in it his entire family as well as animals of all types, and that is indeed what happened.

The biblical text does not mention any events that occurred in the ark during the flood. The impression formed by the verses is that life in the ark involved no problems and everything seems to have proceeded smoothly (7:15-8:19). The creatures in the ark existed harmoniously side by side predators and prey, the dominant and the subservient - with no territorial boundaries, tensions, or rivalries. The authors of the midrash note the silence of the scriptures and some of them refute the impression formed by the text. The midrashim present rivalries among the animals and also point to the violation of moral norms, which included acts that were prohibited for the dwellers of the ark.

\footnotetext{
1 The citations from the Bible in this paper are according to Revised Standard Version [RSV].

2 Extensive literature written on the subject suggests different ways of understanding the literary, theological, and philosophical foundations of the story. See for example, CASSUTO, 1959, p. 32-78.

3 The Aggadic homilies also called "Aggadic midrashim" (in Hebrew "Midrashei Aggada"), that is Talmudic collection of legends based on biblical verses (non-legal portions of the Bible).
} 


\section{Purpose of the study and research questions}

The main purpose of this article is to discuss midrashim that portray negative occurrences within the ark. I shall focus on three midrashim. One deals with forbidden sexual relations in the ark, the second relates to the rivalry and confrontation between the cat and the mouse, and the third is about the lion that injures Noah and renders him disabled. In this article I shall focus on two main questions:

a) What is the theological-educational message that the midrashim wish to convey through the narrative of these occurrences?

b) From where did the sages derive the new contents that are not explicitly mentioned in the text? And why did they attribute improper sexual behavior to certain creatures within the ark?

\section{The forbidden sexual intercourse of Ham, the raven and the dog}

The author of the Midrash mentions a prohibition against sexual intercourse in the ark. The prohibition is not mentioned explicitly in the biblical text and it is learned from homiletic interpretation of the verses (JERUSALEM TALMUD, 1523, Ta'anit 1:6, 64d; BABYLONIAN TALMUD, 1882, Ta'anit 11a; GENESIS RABBAH, 1885-1887, 31:13, p. 130).

The Midrash notes that all the creatures obeyed the ban aside from three, among them the dog:

Our Rabbis taught: Three copulated in the ark, and they were all punished - the dog, the raven, and Ham. The dog was doomed to be tied, the raven expectorates [his seed into his mate's mouth], and Ham was smitten in his skin (BABYLONIAN TALMUD, 1882, Sanhedrin 108b).

According to the version of GENESIS RABBAH (1885-1887, Noah, $36: 7$, p. 149) only Ham and the dog copulated in the ark and were punished:

Rabbi Hiya said: Ham and the dog copulated in the ark, therefore Ham came forth black-skinned while the dog publicly exposes its copulation. Rabbi Levi said: This may be compared to one who minted his own coinage in the very palace of the king, whereupon the king ordered: I decree that his effigy be charred [in Hebrew: mephuham=dark, defaced] and his coinage cancelled. Similarly, Ham and the dog copulated in the Ark [and were punished]. Accordingly, Ham became mephuham [=defaced] and the dog is known in his copulation 
Each of the three creatures sinned and was punished for his sin:

1. Ham - bore Kush whose skin was dark and was therefore considered inferior by the ancients. ${ }^{4}$ Similar tradition is found in early Christian literature. Mar Ephrem the Syrian, a Christian theologian and church father of the fourth century (d. 373 CE) says: "When Noah awoke and was told what Canaan did [...] Noah said, 'Cursed be Canaan and may God make his face black". And immediately the face of Canaan changed" (GOLDENBERG, 2017, p. 88).

2. The dog - The dog's problematic sexual behavior was also noted in another Midrashic source, whereby it copulated with the wolf even before entering the ark (GENESIS RABBAH, 1885-1887, p. 121). It was punished that it does not easily separate from the female after copulating, a realistic description. After copulation, the male passes one front leg and one back leg over the female's back, and while connected he turns his body around. Both mates remain in this position, back to back, for several minutes (up to 20) until the semen is deposited. In this state the mates cannot easily separate (in the words of the Midrash: "they are tied") until the semen is deposited (MENDELSSOHN and YOM-TOV, 1990, p.180).

3. The raven - "spits semen from its mouth to that of the female" (see the commentary of Rashi there), i.e., it reproduces differently than other animals, which copulate using sex organs (On the raven in the Bible and early Rabbinic literature See TRISTRAM, 1898, p. 198; FELIX, 1972, p. 112).

The male raven passes its semen to the female from beak to beak. The punishment may be that the act involves no pleasure, and in any case, this is not a realistic phenomenon. ${ }^{5}$ The punishments given to the dog and to the raven follow the "measure for measure" rule (lex talionis). Since their sin was sexual they are punished with irregular sexual conduct.

The struggle between the cat and the mice in the ark

The Midrash in Genesis Rabbati clarifies the question of why Noah was considered righteous, as the scriptures do not specify his good deeds. The Midrash assumes that Noah's righteousness did not stem from avoiding

On the curse of Ham see at length GOLDENBERG, 1997, p. 21-51; GOLDENBERG, 2003, p. 141-177. On the image of the black in Rabbinic literature see MELAMED $\square$, 2003. On the image of the black in the non-Jewish cultures in ancient times (in Greece and Rome) see SNOWDEN, 1970; SNOWDEN, 1983); THOMPSON, 1989; MIREILLE $\square$, 2015, p. 33-53.

5 According to another Aggada the raven was originally white, but like Cham was punished with blackness because it did not return to the Ark. See at length PAZ, 1990, p. 422; GOLDENBERG, 2003, p. 99-100. Goldenberg (ibid, p. 287) also has shown that the belief of turning black of the raven is found in Ovid's (d. 18 C.E.) Metamorphoses 2.531. 
bad deeds, rather he himself performed good actions. The exegetist notes that Noah behaved beneficently towards all the animals in the ark and he focuses on one episode - Noah's treatment of the mouse who was injured by the cat and required medical care:

]For I have seen that you are] righteous before me [in this generation]" [Genesis 7:1]. Why righteous? Because he performed righteous deeds to all those in the ark. It is said that at first, in the time of Adam, there were a cat and a mouse in Adam's abode and initially they shared everything. One day the mouse began to entertain in its heart competition towards the cat and it went to Adam and said to him: Master, give me permission to kill the cat, because it is a thief and a gambler. Adam said to it: Because you have spoken ill of it you will become its food. Immediately, the cat jumped on the mouse and killed it. The mouse's pups and mate saw this and fled to the mountain crannies, rock crevices, and dirt holes. They also said: There shall be no refuge from the cat our enemy. When Noah came and brought them into the ark, on the first day the cat and its mate stood by each other. The cat said to its mate: I remember that when I was a baby, father brought me one of these and I ate it and it was good food. Now I shall chase it and catch it and eat it. The mouse heard this and fled and the cat chased it, and a miracle occurred to the mouse and it found a small hole and entered it. The cat put its paw into the hole to draw it out and the mouse bit it. The cat too cut the mouse's bottom lip with its claw, to a depth of half a finger. Some time passed and the mouse went to Noah and said to him: Righteous man, do right by me and sew up what the cat my enemy tore. He said to it: Go and bring me a piece of its hair. It went to the cat and found it asleep and took of its hair and returned to Noah who sewed its cut. For this he is called a righteous man [Genesis 6: 9] (ALBECK, 1940, Noah 7:1).

The Midrash before us is an etiological story that offers an explanation of the "eternal conflict" between the cat and the mouse, and the Midrash seems to be referring to the house mouse (Mus musculus) (SEELIGMANN, 1997, p. 432-460). Mice, who belong to the rodent family, are the natural food of the cat, as a carnivore. Wild cats, for instance, eat mainly rodents (Rodentia), and these constitute 90 percent of their food (MENDELSSOHN and YOM-TOV, 1990, VII, p. 214).

According to the Midrashic narrative, at first, when Adam was still in the Garden of Eden, the relationship between the mouse and cat was positive and friendly, compatible with the idyllic utopian world before the primordial sin. At some stage, the mouse began to compete with the cat. It 
informed Adam that the cat is a corrupt and negative creature and requested permission to kill it. Adam became angry at the mouse for speaking ill and cursed it with the fate of becoming the cat's prey. Consequently, the mouse was forced to flee with its pups to hidden places, such as holes and crannies, which are in fact its natural habitat. The exegetist assumed that the mouse was responsible for its fate and had brought it upon itself. This Midrash joins other Jewish sources that perceive the mouse to be an inferior creature, one that is harmful and evil and thus deserving of a bad and bitter fate (JERUSALEM TALMUD, 1523, Baba Metzia 3:4, 9b; BABYLONIAN TALMUD, 1882, Orayot 13a. In classical literature the mouse is a symbol of lechery and destruction and it symbolizes avarice, greed and thievery. See WERNESS, $\square$ 2006, p. 285).

The escape and the distance from the cat did not last long, and during the flood the mouse family met the cat once again in Noah's ark. Living in the same space renewed the friction between the rivals and the cat, which had not seen the mouse for a long time, remembered the good taste of its flesh. The mouse fled the cat, but the latter managed to get its claws in and deeply cut the mouse's bottom lip, which may allude to its sin, talking bad of the cat (measure for measure). The mouse who knew of Noah's righteousness, apparently from his treatment of the other animals while in the ark, asked Noah to treat its cut. Noah sewed up the cut with a hair from the cat itself, possibly alluding to the therapeutic approach of curing an injury by using its cause, while according to another version the cut was sewn with a pig's hair (EISENSTEIN,1915, I, p. 65).

The exegetist illustrates Noah's general righteousness towards creatures through a story that involves Noah's dedicated medical care of the mouse. Noah's quality of righteousness was noted in the biblical text twice before entering the ark (Genesis 6:6; 7:1). Hence, the exegetist saw Noah's activity in the ark as an expression of his overall goodness, which was the initial reason that he was chosen to continue human existence. As we stated above, various Midrashim note that the corruption demonstrated by Noah's generation (Genesis 6:11-12) was evident mainly in their deficient social morals and harm to other people and to property, i.e., theft and evil doing (BABYLONIAN TALMUD, 1882, Sanhedrin 108b; ALBECK, 1940, Bereshit 6:2). Hence, in contrast to his generation, Noah was a person of benevolence and helping others, even the most inferior creatures such as the mouse. Not only did he not harm the creatures, rather he helped them, as he did in the ark by healing 
the mouse (On Noah as a healer in the Midrashic literature see JELINEK, 1967, p. 155; NOY, 1970, p. 68-93).

It appears that the exegetist wished to convey another message as well. The hatred and the conflict between rival creatures did not cease while in the ark - everything continued as before. Noah's act reflects man's role in coping with natural instincts. He can't change the nature of the cat or, according to the Midrash, "Adam's decree", but he corrects the wrong that the cat inflicted on its rival. Between the lines it is possible to note the exegetist's critical approach to Adam's chosen course in the fight between the cat and the mouse.

Due to the mouse's errant behavior, Adam decrees that he be prey to the cat. He does not initiate any reconciliation or propose a correction of their relationship, rather affixes the rivalry for all time in favor of the cat. This rivalry continues even when humanity goes through a process of rebuilding, towards a better world. Noah is incapable of revoking the curse that Adam put on the mouse, and apparently also of reconciling the mouse and the cat. Nevertheless, he is not insensitive to the mouse's pain despite its "wickedness" and treats it sensitively.

\section{The lion injures Noah and renders him disabled}

Several midrashim speak of Noah's devotion in caring for the animals, considering the difficulties involved. Aside from preparing the proper type of food for each of the animals in advance, in the ark Noah had to feed each of them at the appropriate time - nocturnal animals at night and animals active in the daytime during the day. Naturally, the many types of animals meant that Noah was compelled to work ceaselessly around the clock with no real rest (BABYLONIAN TALMUD, 1882, Sanhedrin 108b; BUBER, 1885, Noah, section 2: 29).

One of the midrashim relates that the lion injured Noah for not feeding him on time: "Once he was late in feeding the lion, and [the lion] struck him on his feet and he became lame" (BUBER, 1894, Noah, 7:23, p. 18-19). The lion (Panthera leo) is a large predator that consumes large quantities of meat. ${ }^{6}$ The lion's preying urge is very strong and it might react dangerously

Adult male lion can eat $43 \mathrm{~kg}$ in a day and a female may eat over $25 \mathrm{~kg}$. The estimated minimum daily requirement of meat of lioness per day is 5 to $8 \mathrm{~kg}$, and of a male is about 7-9 kg per day. See SCHALLER $\square$, 1972, p. 267-279, and compare SUNQUIST and SUNQUIST $\square$, 2002, p. 291-292. 
when hungry. The lion, whose paws are strong and forceful, injured Noah and rendered him lame. It appears that the exegetist was interested not only in indicating the lion's apparent ungratefulness at Noah's devoted care, rather also that the lion's natural urges did not change and it remained a dangerous predator capable of doing harm.

\section{Discussion and Conclusions}

This article encompasses a discussion of three midrashim that describe negative occurrences in the ark - not maintaining the prohibition against sexual relations during the flood, friction between animals who are natural enemies, and the tension between Noah and the hungry lion. What is the theological-educational message that the midrashim endeavor to convey? What motivated the exegetists to question the simple impression of a positive atmosphere in the ark, which was allegedly intended to facilitate the correction and renewal of the world?

According to the biblical text, the ark was supposed to help the chosen creatures survive the flood so that they could initiate a more correct world. Namely, the ark was a temporary stage of transition between the old broken world and the new world that would exist after leaving the ark. Various midrashim stress man's responsibility for nature and for the environment as encompassed in the pre-flood commandment "to work it and take care of it" (le-Ovda u-le-Shomra)." (KOHELET RABBAH, 1885-1887, 7:13, p. 39; HARSHEFER, 1994, p. 57). This responsibility belongs to Noah, as the ark with its many varied inhabitants is a microcosmos that requires preservation. Noah, who cared for the animals so that they will survive the holocaust of the flood, reflects the role of the "intelligent creature" who tops the ecological pyramid by caring for all creatures so that they will continue to live together in a balanced system (ROZENSON, 2001, p. 49-51). Hence, caring for the animals is a return to the initial ideal Creation and part of the process of correcting the moral injustices that had become prevalent among human beings. Caring for the animals is a manifestation of giving, loving kindness, and concern for others, and it constitutes a moral response to the egotism and aggressiveness that had spread among those of Noah's generation.

Renewal of the world or "The Second Genesis" means being granted another opportunity to establish a moral world with regard to sexual matters as well (On the term "The Second Genesis" see SHAVIT, 1988-1989, p. 9-10). According to the sages of the midrash, the flood was preceded by a state 
of sexual promiscuity where living creatures, both human and animal, had sexual relations with other species, unlike our current world but assumedly compatible with beliefs in the ancient world: "'Everyone committed improper deeds in the generation of the flood, the dog with the wolf, the rooster with the peacock" (GENESIS RABBAH, 1885-1887, 28:8, p. 121. See also BABYLONIAN TALMUD, 1882, Sanhedrin 108b and FELIX, 1967, p. 117135). The sages' interpretation that during the flood the ark dwellers were prohibited from sexual relations was explained by the convention that during grave occurrences and events, such as times of destruction or hunger, new life should not be introduced into the world (JERUSALEM TALMUD, 1523, Ta'anit 1:6, 64d; BABYLONIAN TALMUD, 1882, Ta'anit 11a; GENESIS RABBAH, 1885-1887, 31:13, p. 130). This prohibition seems to have had another benefit - it calmed or restrained for a short while the boundless sexual urges characteristic of the generation of the flood.

The verses preceding the description of the flood relate that God reached a conclusion "that every imagination of the thoughts of his heart was only evil continually" (Genesis 6: 5). Did the flood change the nature of human and of the different creatures? Did they cease to sin and corrupt? It appears that they did not. After Noah left the ark, he offered sacrifices from among the animals that had survived (Genesis 8:20). The good scent of the sacrifices satisfied God, who consequently decided that he would never bring another flood upon the world, as destroying the world would do no good since human urges remained evil (Genesis 8:21). The midrashim relating that which occurred within the ark strengthen the insight whereby the evil urges of the creatures, and first and foremost of humankind, did not change, and the attempt to create a new ideal and sinless system did not meet with success.

As seen above, the attempt to restrict sexual relations during the flood did not succeed, and the prohibition was violated by $\square \mathrm{am}$, the dog, and the raven, who represent three major groups in the world, i.e., humans, beasts, and fowl. The inability to obey the prohibition indicates how difficult it is for creatures of various types to maintain sexual restraint. According to the biblical story, a sin involving sexual morality is committed immediately after leaving the ark. Noah plants a vineyard, drinks the wine, and becomes drunk and uncovered in his tent (9:20-24) (On wine and Loss of control as causes of sin in the Midrashic literature see SHEMESH, 2018, p. 171-183). Hence, the midrash anticipates the biblical text and shows that already in the ark were there incidents of forbidden sexual relations. 
The rivalry and conflict between the creatures, evident prior to entering the ark, do not cease and even become aggravated. The cat continues to pursue the mouse, as it did even in the time of Adam, and leads to its injury. Moreover, while before the flood the mouse kept its distance from the cat and chose to live in a distant habitat, dwelling together in the ark due to the flood reignited their rivalry, which was in fact inevitable.

Other midrashim indicate that the potential for sin existed in the ark, although it was only realized after leaving it. One example is the midrash whereby Noah brought to the ark fig shoots and vine branches with the positive thought of feeding the beasts and animals (GENESIS RABBAH, 1885-1887, 31:14, p. 130; ibid, 36: 3, p. 147; THEODOR-ALBECK, 1903, p. 287). After leaving the ark Noah planted the remaining branches and produced wine from the vineyard, leading to his drunkenness and shame. Hence, subconsciously as well, the potential for the sin of drunkenness and nakedness already existed in the ark.

From whence did the sages of the midrash derive the narrative on the improper sexual conduct of $\square \mathrm{am}$, the dog, and the raven? Are there allusions to this in the biblical text? With regard to $\square \mathrm{am}$, the underlying element is probably the subsequent story about Noah's drunkenness and his uncovering in the tent. According to the simple meaning of the verses, $\square$ am committed a sexual $\sin -$ it is said of him that he "saw his father's nakedness" and did not cover Noah's nakedness like his two brothers (9:22-23). Some homiletic exegetists identified much more radical acts in the text $-\square$ am castrated or sodomized his father, i.e. committed the grave sin of incest (BABYLONIAN TALMUD, 1882, Sanhedrin 70a).

This understanding is based on the meaning of the phrase "to see nakedness" in parallel sources, which means to have sexual relations (See Leviticus 20:17: "If a man takes his sister [...] and sees her nakedness, and she sees his nakedness, it is a shameful thing"), and perhaps also on the parallelism between "lay uncovered inside his tent" and incest in other sources (Leviticus 20:17 If a man lies with a woman having her sickness, and uncovers her nakedness [...] and she has uncovered the fountain of her blood"). This story reveals $\square$ am's sexual promiscuity and therefore the exegetist allows himself to presume that he behaved similarly when in the ark as well, although the verses themselves clearly contain no proof of this.

The raven's carelessness about maintaining the prohibition against copulation during the flood appears to be related to its general "disloyal 
and irresponsible" image. ${ }^{7}$ According to the biblical text, the raven does not accept the role that Noah gave it to check whether the water had receded (Genesis 8:7). The midrash literature relates that instead of fulfilling its mission on behalf of the collective the raven focused on itself - eating the corpse of a man who had died in the flood. ${ }^{8}$

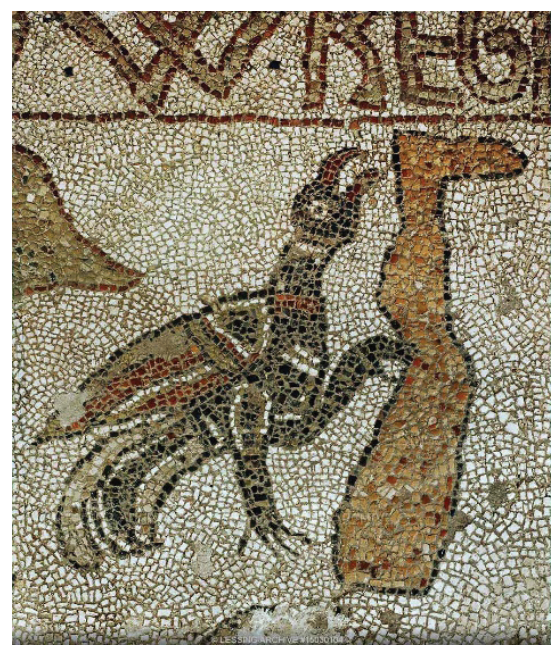

Figure 1: Raven picking at a dead man's leg during the Flood. Mosaic (12th century) Cathedral, Otranto, Italy

Other midrashim deal with sexual associations related to the raven. One midrash claims that the raven refused to carry out the mission given it by Noah in concern that Noah intended to arrange for it to die in the stormy weather and then take its mate for himself (BABYLONIAN TALMUD, 1882, Sanhedrin 108b, and compare to the version of GENESIS RABBAH, 18851887 , Noah $33: 5$, p. 138). This midrash too clearly expresses the atmosphere of sexual infidelity that had spread among all creatures.

7 According to Philo of Alexandria (1st century CE), the raven in Noah's story symbolizes vice, whereas the dove symbolizes virtue. see PHILO, 1953, 2:38, p. 114-116. Because of the characters of the ravens (their dark color, being carrion fowls and their unpleasant voice) they were associated with the dead and bad news. On the controversial image of the raven and its symbolism in the ancient cultures see LÉVI-STRAUSS, 1955, p. 428-444.

8 HOROWITZ, 1972, p. 81. The tradition of the raven eating a corpse of a man is found in the Byzantine composition Palaea Historica ("The Old Testament History"). See FLUSSER, 1971, p. 48-79. The motif of the Raven picking at a dead man's leg (or dead animal) during the Flood is also preserved in the Mosaic in the Cathedral of Otranto, Italy, 12th century (See figures 1-2). 


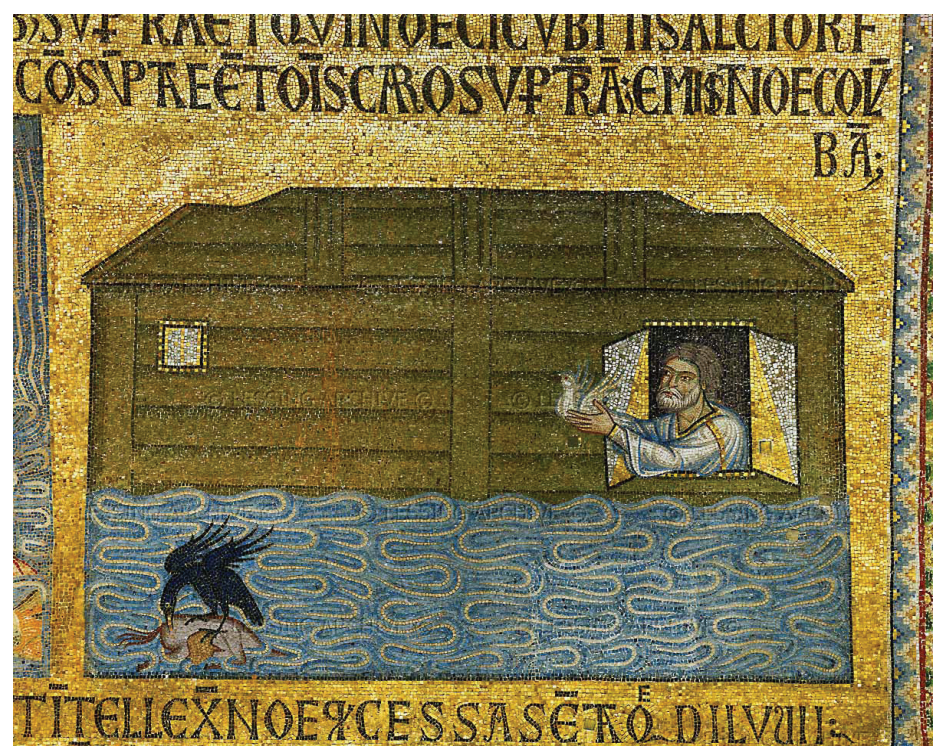

Figure 2: Raven eating dead animal during the

Flood while Noah releasing the dove.

The atrium of the basilica, Church S. Marco, Basilica, Venice, Italy

Another midrash notes that the raven suspected that its mate had copulated with others, explaining why its chicks' feathers are white rather than black (In fact, Ravens, like all other corvids (Corvidae), are monogamous, so this Midrashic tradition has no base in the reality. See CLAYTON and EMERY, 2007, p. R652-R656). This conclusion led the raven to abandon its chicks and leave them to hunger, in the claim that it is not their father (LEVITICUS RABBAH, 1885-1887, 19:1; BUBER, 1885, Ekev, siman 3). Namely, it is unfaithful to its mate and irresponsible towards its progeny.

The midrash relating the story of the lion that injured Noah for not feeding it also stresses the understanding that it is not possible to produce an ideal system that contains no basic urges. The natural needs (consuming food, the sexual urge) are extremely strong and cannot be changed or uprooted, and sometimes when they are not satisfied this might lead to violence. Hence, Isaiah's utopian ideal of "The wolf will live with the lamb" (Isaiah 11:6) is an eschatological vision and the natural world works differently.

In summary, the story of the Creation in Genesis 1 is God's story and not man's story. The image of the world as it appears in Chapter 1 is a 
model for which we must strive, a type of vision or ideal. According to the primeval narrative, humans are situated within a framework. On one hand, they have no impact on the foundations of the eternal creation, and on the other, they have a role in developing the land and in maintaining it. The story of humankind, with its urges and weaknesses, indicates an intelligent creature that is incapable of upholding an ideal reality, and therefore the sin and the decline are inevitable.

The story of the ark continues the "story of humankind". The negative occurrences that it contains continue the plot concerning the weaknesses of humans in particular and of all creatures in general. The individuals chosen to begin a new story, one that is allegedly divine-ideal, are once again incapable of performing the mission with which they have been charged. They are motivated by urges instilled in them and therefore God reaches the conclusion that there is no use in annihilating nature and humankind.

\section{Reference}

ALBECK, Hanoch. Genesis Rabbati. Jerusalem: Mekitzei Nirdamim and Mossad Ha-rav Kook, 1940.

BABYLONIAN TALMUD. Vilna: The Widow and Brothers Romm, 1882.

BUBER, Solomon. Midrash Aggadah. Vienna: Abraham Fanta, 1894.

BUBER, Solomon. Midrash Tanḥuma. vol. II: Exodus and Deuteronomy. Vilna: Solomon Buber, 1885.

CASSUTO, Moshe David. From Adam to Noah: A Commentary on the Book of Genesis I-VI. Jerusalem, Magnes, 1959. (Heb.)

CLAYTON, Nicola S. and EMERY, Nathan J. The social life of corvids. Current Biology, v. 17[16], p. R652-R656, 2007.

DALE, Patrick. Old Testament Law. Atlanta, GA: John Knox, 1985.

EISENSTEIN, Yehuda David ben Ze'ev Wolf. Otzar Mirashim. New York: Y.D. Eisenstein 1915.

FELIX, Yehuda. Mixed Sowing Breeding and Grafting. Tel Aviv: Dvir, 1967. (Heb.)

FELIX, Yehuda. The Animals in the Mishnah. Jerusalem: The Mishnah Research Institute, 1972. (Heb.)

FLUSSER, David. Palaea Historica An Unknown Source of Biblical Legends. Scripta Hieroslymitana, v. 22, p. 48-79, 1971.

GENESIS RABBAH. Vilna: The Widow and Brothers Romm, 1885-1887. 
GOLDENBERG, David M. The Curse of Ham: Race and Slavery in Early Judaism, Christianity, and Islam. Princeton and Oxford: Princeton University Press, 2003.

GOLDENBERG, David M. Black and Slave: The Origins and History of the Curse of Ham. Berlin-Boston: Walter de Gruyter GmbH \& Co KG, 2017.

GOLDENBERG, David M. The Curse of Ham: A Case of Rabbinic Racism? In: Jack Salzman and Cornel West (eds.). Struggles in the Promised Land. New York-Oxford: Oxford University Press, 1997, p. 21-51.

HAR-SHEFER, Zvi. Ecology in Jewish Heritage. Haifa: Shaanan College Publication, 1994. (Heb.)

HOROWITZ, Haim Meir. Pirke d'Rabbi Eliezer (Attribute to R. Eliezer ben Horkenos). Jerusalem: Makor, 1972 (Venice manuscript, 1544).

HOROWITZ, Haim Saul. Sifri on Numbers and Sifri Zuta. Leipzig: Kaufman 1917.

JELINEK, Aron (Adolf). Beit Ha-Midrash, vol. III. Jerusalem: Verman, 1967.

JERUSALEM TALMUD. Venice edition. Venice: Daniel Bomberg, 1523.

Kil, Yehuda. Sefer Bereshit with commentary Daat Mikra. Jerusalem: Mossad Harav Kook, 1997. (Heb.)

KOHELET RABBAH. Vilna: The Widow and Brothers Romm, 1885-1887.

LÉVI-STRAUSS, Claude. The Structural Study of Myth. The Journal of American Folklore, v. 68[270], Myth: A Symposium, p. 428-444, 1955.

LOEWENSTAMM, Samuel Ephraim. Mishpat, Mishpat ha-mikra. In: Tur-Sinai, Naftali H. and others (eds.). Enziklopedya Mikrait [=Biblical Encyclopedia], vol. V. Jerusalem: Bialik Institute Publishing, 1968, p. 614-636. (Heb.)

MELAMED, Abraham. The Image of the Black in Jewish Culture: A History of the Other. New York: Routledge, 2003.

MENDELSSOHN, Heinrich and YOM-TOV, Yoram. Canidae. In: Alon, Azaria (ed.). Plants and Animals of the Land of Israel: An Illustrated Encyclopedia, vol. VII: Mammals. Tel Aviv: Ministry of Defense, 1990, p. 180-189. (Heb.)

MIREILLE M. Leê. Body, Dress, and Identity in Ancient Greece. New York: Cambridge University Press, 2015.

NOY, Dov. The attitude of the Aggada to Medicine. Ma'anayim, v. 122, p. 68-93, 1970.

PAZ, Uzi. Raven, Crvus. In: Alon, Azaria (ed.). Plants and Animals of the Land of Israel: An Illustrated Encyclopedia, vol.VI: Birds. Tel Aviv: Ministry of Defense, 1990, p. 422429. (Heb.)

PHILO. Questions and Answers on Genesis. R. Marcus (trans.). Cambridge, Mass. and London: Harvard University Press and William Heinemann, 1953.

ROZENSON, Israel. It Was Very Good. Jerusalem: Beit Orot, 2001. (Heb.) 
The narrative of the "uncalm ark" in the Aggadic homilies

SCHALLER, George B. The Serengeti Lion: A Study of Predator-Prey Relations. Chicago and London: University of Chicago Press, 1972.

SEELIGMANN, Itzhak Arie. Etiological Foundations in the Biblical Historiography. In: Mordechai Cogan (ed.). Studies in Biblical History. Jerusalem: Zalman Shazar Center for Jewish History, 1997, pp. 432-460.

SHAVIT, Jacob. This is the Story of Noah and the Flood: The Creation in the Second Time. Moznaim, v. 62, p. 9-10, 1988-1989. (Heb.)

SHEMESH, Abraham O. Was the Tree of Knowledge an Apple Tree? Jewish, Christian and Islamic Traditions of the Identification of the Biblical Tree of Knowledge. In: Abraham Gottlib (ed.). Worlds meet: the sciences in the Jewish world. Ramat Gan: Bar-Ilan University, The Helene and Paul Shulman Center for Basic Jewish Studies, 2018, p. 171-183. (Heb.)

SKINNER, John. A Critical and Exegetical Commentary on Genesis (International Critical Commentary). New York: Charles Scribner's Sons, 1910.

SNOWDEN, Frank. Before Color Prejudice: The Ancient View of Blacks. Cambridge, Mass.: Harvard University Press, 1983.

SNOWDEN, Frank. Blacks in Antiquity: Ethiopians in the Graeco-Roman Experience. Cambridge, Mass.: Belknap Press of Harvard University Press, 1970.

SUNQUIST, Mel and SUNQUIST, Fiona. Wild Cats of the World. Chicago and London: University of Chicago Press.

THEODOR, Yehuda \& ALBECK, Hanoch. Genesis Rabbah. Berlin: Zvi Hirsch Itzkowski, 1903.

THOMPSON, Lloyd. Romans and Blacks. Oklahoma: Norman, 1989.

TRISTRAM, Henri Baker. Natural History Bible. London: Society Promoting Christian Knowledge, 1898.

WERNESS, Hope B. Continuum Encyclopedia of Animal Symbolism in World Art. New York: Continuum, 2006.

Submetido em: 2-10-2020

Aceito em: 21-1-2022 